УДК 656.34:338.47

\title{
РАЦІОНАЛЬНЕ ВИКОРИСТАННЯ РЕЙКОВОГО ТРАНСПОРТУ У ВЕЛИКИХ МІСТАХ УКРӒ̈НИ
}

\author{
Бараш Ю. С., д.е.н., професор, \\ Адамян Ю. П., асистент (ДНУЗТ)
}

\begin{abstract}
Мета. Метою статті $\epsilon$ удосконалення термінологічного поняття «міський рейковий транспорт», щзо дозволить раціонально використовувати усі види рейкового транспорту у великому місті та оптимізувати витрати на їх розвиток і експлуатацію. Для скорочення витрат місиевих бюджетів при перевезенні населення з приміської зони у велике місто необхідно розвинути існуючу класифікачію пасажирських поїздів в Украӥні, і додатково включити в неї міський залізничний рейковий транспорт. Методика. В роботі застосовані методика визначення оптимальних зон курсування приміських поїзді та принщипи побудови класифікаџії пасажирських поїздів в Україні. Результати. Проаналізована діяльність усіх видів міського рейкового транспорту, визначені рачіональні сфери їх використання, особливу увагу приділено залізничним видам транспорту, які одночасно можуть курсувати на теренах залізниці та у межах великого міста. Враховуючи сказане, набула подальшого розвитку існуюча класифікація пасажирських поїдів в Україні. Наукова новизна. На основі досліджень запропоновано удосконалене термінологічне поняття «міський рейковий транспорт», яке відрізняється від існуючого включенням усіх можливих видів рейкового міського транспорту, щчо дозволить рачіонально використовувати їх у великому місті та оптимізувати витрати на розвиток та експлуатацію міського транспорту. Набула подальшого розвитку існуюча класифікація пасажирських поӥздів в Украӥні, яка додатково включає міський рейковий транспорт, для якого застосовуються залізничний рухомий склад, а саме електропоїзд та рейковий автобус, що дозволить скоротити витрати місцевих бюджетів при перевезенні населення з приміської зони у велике місто. Практична значимість. Використання удосконаленого термінологічного поняття «міський рейковий транспорт» дозволить рачіонально використовувати усі види рейкового транспорту у великому місті та оптимізувати витрати на їх розвиток і експлуатацію. Впровадження удосконаленої класифікації пасажирських поӥздів в Україні дозволить розширити кордони експлуатації залізничного транспорту та скоротити витрати місиевих бюджетів при перевезенні населення з приміської зони у велике місто.
\end{abstract}

Ключові слова: міський транспорт, рейковий транспорт, пасажирські поӥзди, класифікація.

\section{РАЦИОНАЛЬНОЕ ИСПОЛЬЗОВАНИЕ РЕЛЬСОВОГО ТРАНСПОРТА В БОЛЬШИХ ГОРОДАХ УКРАИНЫ}

\author{
Бараш Ю. С., д.э.н., профессор, \\ Адамян Ю. П., ассистент (ДНУЖТ)
}

Цель. Целью статьи является совершенствование терминологического понятия «городской рельсовый транспорт», что позволит рационально использовать все виды рельсового транспорта в большом городе и оптимизировать затратьл на их развитие и эксплуатацию. Для сокращения расходов местных бюджетов при перевозке населения с пригородной зоны в большой город необходимо развить существуюшую классификацию пассажирских поездов в Украине, и дополнительно включить в нее городской железнодорожный рельсовый транспорт. Методика. В работе применень методика определения оптимальных зон следования пригородных поездов и принципь построения классификации пассажирских поездов в Украине. Результаты. Проанализирована деятельность всех видов городского рельсового транспорта, определены рациональные сферы их использования, особое внимание уделено железнодорожным видам транспорта, которые одновременно могут курсировать на территории железной дороги и в пределах большого города. Учитьввая сказанное, получила дальнейшее развитие существующая классификация пассажирских поездов в Украине. Научная новизна. На основе исследований предложено усовершенствованное терминологическое понятие «городской рельсовый транспорт», которое отличается от существующего включением всех возможных видов рельсового транспорта, что позволит рациинально использовать их в большом городе и оптимизировать затратьл

(C) Бараш Ю.С.,

Адамян Ю.П.

Вісник економіки транспорту і промисловості № 52, 2015 
на их развитие и эксплуатациию. Получила дальнейшее развитие существующая классификация пассажирских поездов в Украине, которая дополнительно включает городской рельсовый транспорт, для которого применяются железнодорожный подвижной состав, а именно электропоезда и рельсовый автобус, что позволит сократить расходы местных бюджетов при перевозке населения с пригородной зоньл в город. Практическая значимость. Использование усовершенствованного терминологического понятия «городской рельсовый транспорт» позволяет рационально использовать все виды рельсового транспорта в большом городе и оптимизировать затраты на их развитие и эксплуатацию. Внедрение усовершенствованной классификации пассажирских поездов в Украине позволит расиирить границь эксплуатации железнодорожного транспорта и сократить расходы местных бюджетов при перевозке населения с пригородной зоны в большой город.

классификация.

Ключевые слова: городской транспорт, рельсовый транспорт, пассажирские поезда,

\section{RATIONAL USE OF URBAN RAIL TRANSPORT IN THE BIG CITIES OF UKRAINE}

\section{Barash Yu. S., Doctor of Economics, Professor, Adamyan Yu., Assistant, (Dnipropetrovsk National University of Railway Transport named)}

The purpose. The aim of the article is to improve the terminology of the concept of "urban rail transport", which will allow efficient use of all types of rail transport in large cities and optimize the costs of its development and operation. To reduce costs of local budgets by transportation of people with commuters to the big city is necessary develop the existing classification of passenger trains in Ukraine and additionally include the urban of rail transport. Methods. In work are applied method of determining the optimal zones move suburban trains and principles of classification of passenger trains in Ukraine. Results. Analyzed the activity of all kinds of urban rail transport, defined the scope of their rational use, special attention is paid to the rail mode of transport, which can simultaneously ply on the territory of the railroad and within the big city. In view of this, was further developed existing classification of passenger trains in Ukraine. Scientific novelty. On the basis of studies suggested improved terminological concept of "urban rail transport", which differs from the existing inclusion of all possible forms of rail transport, which will allow rational use of them in a big city and to optimize the costs of its development and exploitation. Has been further developed an existing classification of passenger trains in Ukraine, which further includes urban rail vehicles, which are used for railway rolling stock, namely electric trains and rail bus, which will reduce the costs of local budgets for the carriage of people with of suburban zone into the city. The practical significance. Use improved terminological concept of "urban rail transit" allows rationally use all types of rail transport in large cities and optimize the costs of their development and operation. The introduction of an improved classification of passenger trains in Ukraine will expand the boundaries of operation of rail transport and reduce the costs of local budgets for the carriage of people with of suburban zone to the big city.

Keywords: urban transport, rail transport, passenger train, classification

Постановка проблеми. Міський транспорт - це комплекс різних видів транспорту, що здійснюють перевезення населення і вантажів на території міста і найближчої приміської зони, а також що виконують роботи, пов'язані 3 благоустроєм міста. Надійна і ефективна робота транспорту міста $\epsilon$ найважливішим показником соціально-політичної та його економічної стабільності [1].

Дедалі більше актуальною стає проблема забезпечення охорони навколишнього середовища від шкідливого впливу громадського транспорту. Зниження шкідливого впливу всіх видів громадського транспорту для здоров'я й довкілля досягається 3 допомогою переходу та збільшення застосування екологічних транспортних засобів [2].

На нашу думку, рейковий транспорт найбільш сучасний вид міського пасажирського транспорту, практично нешкідливий для повітряного басейну міста. Разом 3 тим до даної категорії міського транспорту підпадає декілька видів рейкових транспортних засобів, що обумовлює необхідність проведення додаткових досліджень 3 метою визначення нового термінологічного поняття «міський рейковий транспорт» та використання його для удосконалення класифікації пасажирських поїздів в Україні. 
Формування цілей статті (постановка завдання). Метою статті $€$ забезпечення раціонального використання міського рейкового транспорту на основі обгрунтування удосконаленого термінологічного поняття «міський рейковий транспорт», яке відрізняється від існуючого включенням усіх можливих видів рейкового міського транспорту, i дозволяє створити умови для його беззбиткової діяльності та уникнути транспортних проблем населення великих міст за рахунок оптимального фінансування із місцевих бюджетів.

Крім того, для скорочення витрат місцевих бюджетів при перевезенні населення 3 приміської зони у велике місто необхідно розглянути існуючу класифікацію пасажирських поїздів в Україні, і додатково включити в неї той міський рейковий транспорт, для якого застосовується залізничний рухомий склад.

Аналіз останніх досліджень і публікацій та виділення невирішених частин загальної проблеми. 3 переходом на ринкові відносини в Україні, який супроводжувався перебудовою системи господарювання та економічною кризою, спостерігалось руйнування системи міського пасажирського транспорту [3]. Недостатність коштів на іiі утримання викликала постійне зменшення випуску рухомого складу електротранспорту i поступове закриття маршрутів. Звільнений сегмент ринку поступово заповнювався автобусами й легковими автомобілями.

Особливостями розвитку та вдосконалення транспортної системи України та їі складової міському електричному транспорту приділяли увагу як науковці, так і практики. Насамперед слід назвати публікації та наукові дослідження в сфері сталої роботи міськелектротранспорту В. К. Долі [4], І. С. Сфремова [5], Г.А. Варелопуло [6]; в сфері вдосконалення інфраструктури міст В. I. Торкатюка, А. Ю. Паланта [7]; в сфері вирішення завдань щодо теоретичних розрахунків ймовірностей та моделювання роботи транспортних систем М. I. Адаменка $[8,9]$. Однак у наукових розробках практично зовсім не приділено уваги термінологічному поняттю «міський рейковий транспорт», що вказує на актуальність проведення досліджень в даному напрямку.

Проблемою удосконалення класифікації пасажирських поїздів в Україні в останні роки займалися фахівці Укрзалізниці, вітчизняні вчені Пита А. Л. [11], Мельник Т. С. [12]-13, Овчаренко Л. М. [14], Лихушин С. В. [15], Бакалінський О. В.
[16], Бараш Ю. С., Чаркіна Т. Ю.[18]. При цьому аналізом принципів класифікації пасажирських поїздів 3 урахуванням міського рейкового транспорту вони не займалися.

Виклад основного матеріалу

дослідження. Поновлення останнім часом у багатьох країнах світу інтересу до міського рейкового транспорту як до дієвого засобу вирішення транспортних проблем великих міст обумовлює необхідність в узагальненні наявного в даній сфері досвіду для кращого розуміння оптимальних шляхів розвитку.

Розширення діючих, створення або відродження (після тривалої перерви) мереж міського рейкового транспорту супроводжувалися появою нових термінів, якими намагалися охарактеризувати різні типи такого транспорту. Поряд зі старим терміном «трамвай» в обіг увійшли «супертрамвай», «полегшений метрополітен», «залізниця полегшеного типу» та ін. Застосування таких термінів можна пояснити прагненням вказати на абсолютно нову технічну базу цього, здавалося б, давно відомого виду транспорту, підкреслити його сучасність і зробити привабливим для потенційних пасажирів.

Трамвай являється вуличним рейковим видом транспорту з загальним чи відокремленим полотном в основному наземного використання. Перевізна спроможність трамвая знаходиться в межах 12-15 тис. пасажирів на годину. За перевізною спроможністю це другий після метрополітену вид міського пасажирського транспорту. Трамвай економічний за експлуатаційними витратами та екологічно чистий вид міського транспорту. Проте його маневреність в порівнянні 3 іншими вуличними видами транспорту низька; несправності викликають пробки і затори, він створює шум. Однак системи швидкісного трамвая, які почали застосовувати за кордоном, є найбільш доцільним видом масового пасажирського транспорту в великих містах.

Швидкісний трамвай - це різновид легкорейкового транспорту, регулярний швидкісний позавуличний, переважно наземний рейковий вид міського транспорту; це лінії трамваю, повністю, на всій своїй протяжності, відділені від проїжджої частини. Частково підземний швидкісний трамвай, що має підземні станції, називають метротрамом.

Метротрам (також: пре-метро, семі-метро, підземний трамвай) - рейковий міський транспорт підземно-наземного типу; найчастіше окрема трамвайна система, що відповідає всім стандартам швидкісного трамваю, тобто відділена від 
проїжджої частини, але, крім цього, має підземні ділянки.

Метрополітен представляє собою рейковий вид міського пасажирського транспорту 3 відособленим колійним господарством тунельного, наземного чи естакадного виконання.

Швидкісний трамвай на гумовому ходу $є$ технологією рейкового транспорту 3 використанням деяких елементів автодорожнього. Трамваї використовують гумові шини, які котяться по спеціальних доріжках, зроблених 3 бетону або спеціальної сталі. $€$ два варіанти метрополітену на шинному ходу - поєднаний 3 традиційним рейковим і не поєднаний з ним.

Приміські пасажирські електропоїзди поїзди, сформовані 3 вагонів, для перевезення пасажирів та ручної поклажі (багажу) у приміському сполученні. Рухомим складом на приміських лініях можуть використовуватися:

- електропоїзди, що складаються 3 головних, моторних і причепних вагонів;

- рейкові автобуси - автомотриси, призначені для обслуговування швидкісних маршрутів i ділянок з малим пасажиропотоком. Можуть складатися з 1-3 секцій.

Електропоїзди та рейкові автобуси відносяться до моторвагонного рухомого складу, перевагами якого є поліпшена кінематика складу (швидкий розгін і гальмування), невеликий час «розвороту» (зміни напрямку руху) поїзда (особливо у рейкового автобуса).

У зв'язку із наведеним вище, пропонується переглянути i відкоригувати сутність поняття «міський рейковий транспорт», до якого мають ввійти такі спеціальні види міського транспорту, як:

- Трамвай;

- Швидкісний трамвай;

- Метротрам;

- Метрополітен;

- Швидкісний трамвай на гумовому ходу;

- Приміські пасажирські електропоїзди «міська електричка»;

- Рейковий автобус;

- Вагон-трамвай.

Розвиток i функціонування міського рейкового транспорту до 1991 року здійснювались на основі чіткого централізованого планування за участю державного та місцевих бюджетів. При цьому стадії планування та етапи розвитку міського рейкового транспорту визначались потребами в перевезеннях пасажирів на середньостроковий та довгостроковий періоди (5,
10 та 15 років) і необхідними для цих цілей капіталовкладеннями.

Як правило, побудова нових об'єктів та модернізація транспортних засобів здійснювались за рахунок державного бюджету і підкріплялись матеріальними ресурсами. До об'єктів державного планування відносились будівництво метрополітену, трамвайних депо, мостів, шляхопроводів і найважливіших загальноміських транспортних магістралей. В планах соціальноекономічного розвитку великих міст передбачались введення нових трамвайних ліній i об'єктів дорожньо-мостового будівництва.

3 руйнуванням планових основ практично припинився розвиток i значно ускладнилася експлуатація міського рейкового транспорту. Пристосування до нових економічних відносин супроводжувалось негативними процесами усередині галузі. На підприємствах міського рейкового транспорту погіршились експлуатаційні та фінансові показники їх роботи. Найбільш складно стали вирішуватись питання розвитку i реконструкції вулично-дорожньої мережі та оновлення парку рухомого складу. При низькому коефіцієнті випуску рухомого складу на лінію і загальному дефіциті парку почала падати насиченість ліній рухомим складом. Недостатня кількість рухомого складу i його висока зношеність приводили до збоїв в русі, порушенню регулярності та збільшеним інтервалам руху.

Великі міста потребують добре розвинену i ефективну транспортну систему, яка забезпечує взаємозв'язок і взаємодоповнення індивідуального i міського транспорту i яка дає споживачу можливість альтернативного вибору способу транспортного обслуговування в умовах соціально орієнтованої економіки.

В результаті утворення Публічної акціонерної компанії «Української залізниці» будуть відбуватися значні зміни в організації пасажирських перевезень в усіх видах сполучень, оскільки регіони отримають фінансову незалежність і будуть самостійно вирішувати кількість потрібних міських, приміських, регіональних і міжрегіональних поїздів та графік ï руху за умови наявності коштів.

Відповідно фінансування міських рейкових перевезень буде здійснюватись за рахунок місцевих бюджетів великих міст та обласних центрів, тому удосконалена класифікація пасажирських поїздів в Україні прийме вигляд, наведений на рис. 1. 


\begin{tabular}{|c|c|c|c|c|c|c|c|}
\hline \multirow{3}{*}{ 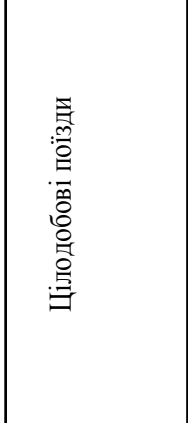 } & \multirow{8}{*}{ 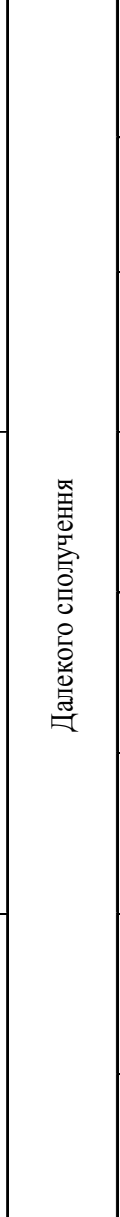 } & 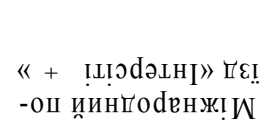 & 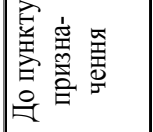 & $\frac{8}{0}$ & 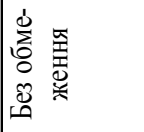 & \multirow{8}{*}{ 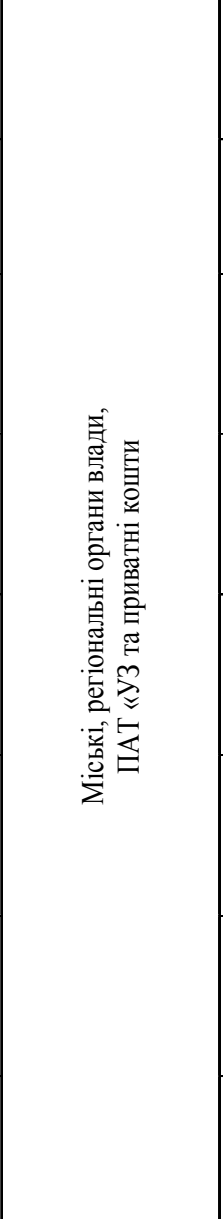 } & 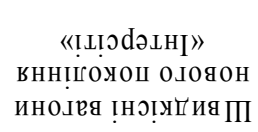 \\
\hline & & 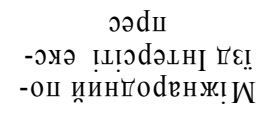 & 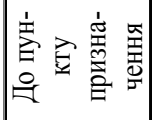 & $\stackrel{\text { 巳 }}{ \pm}$ & 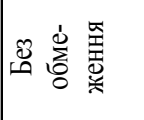 & & 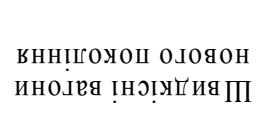 \\
\hline & & 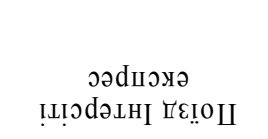 & 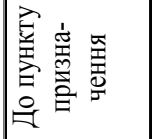 & $\stackrel{\text { ㄱ }}{ }$ & 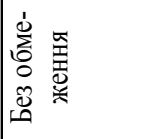 & & 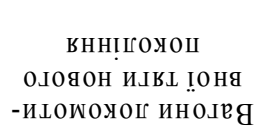 \\
\hline \multirow{3}{*}{ 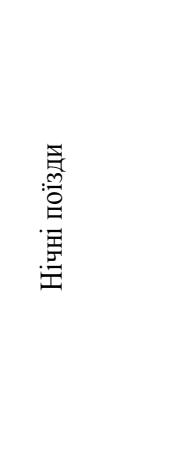 } & & 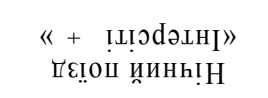 & ஓ & $\frac{8}{8}$ & $\stackrel{\circ}{\circ}$ & & 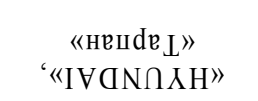 \\
\hline & & 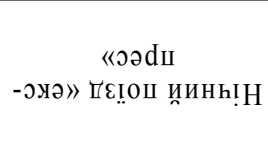 & $\stackrel{\circ}{\circ}$ & 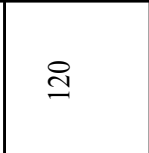 & $\stackrel{0}{0}$ & & 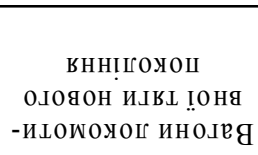 \\
\hline & & 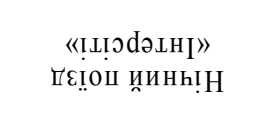 & ஓ & § & $\stackrel{0}{0}$ & & 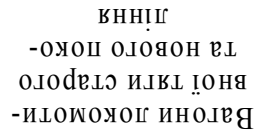 \\
\hline \multirow{7}{*}{ 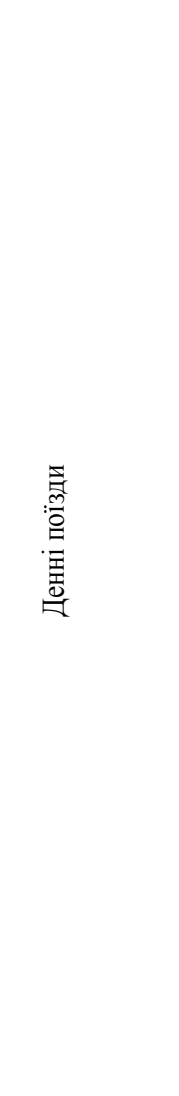 } & & 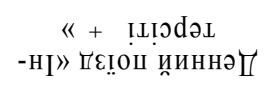 & $\stackrel{\circ}{\circ}$ & $\frac{8}{1}$ & $\stackrel{\circ}{\circ}$ & & $\begin{array}{c}\text { «нешde } L " \\
\text { “IVANกXH" }\end{array}$ \\
\hline & & 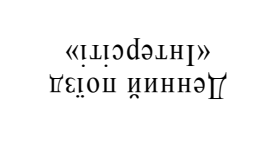 & ஓ̊ & ஃ & $\stackrel{0}{0}$ & & 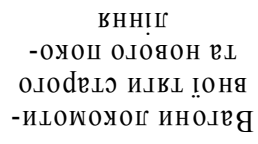 \\
\hline & 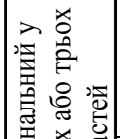 & 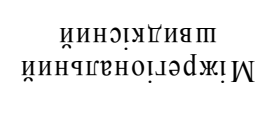 & 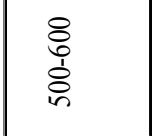 & 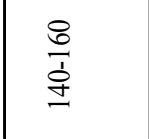 & $\begin{array}{l}0 \\
0 \\
0 \\
0 \\
1\end{array}$ & 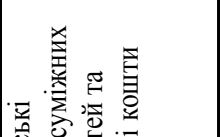 & $\begin{array}{c}\text { вгояП २L } \\
\text { внн!гоя } \\
\text {-ош олояон गдЯW }\end{array}$ \\
\hline & 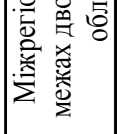 & йинчгеноцЈәдж! & రి & ஓे & $\stackrel{\circ}{\circ}$ & 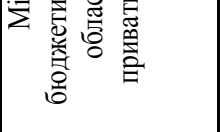 & \multirow{2}{*}{ 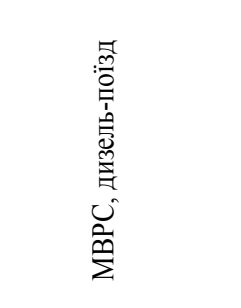 } \\
\hline & 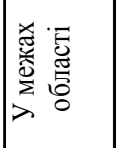 & йлинчггено!ฺә & $\stackrel{\infty}{ }$ & ஓి & ๙̃ & 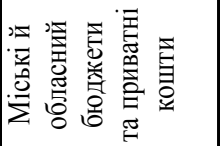 & \\
\hline & 竞罢 & йиячว!̣ииdШ & $\begin{array}{l}\infty \\
i \\
i\end{array}$ & 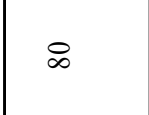 & 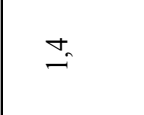 & 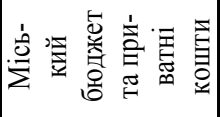 & 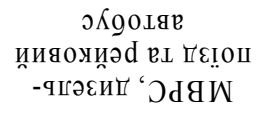 \\
\hline & 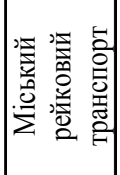 & $\begin{array}{c}\text { Ldoшэне dL } \\
\text { йияояйәd } \\
\text { йиячว! } W\end{array}$ & 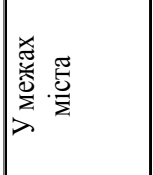 & 尺 & & 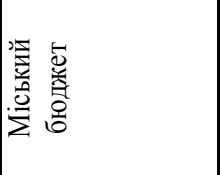 & 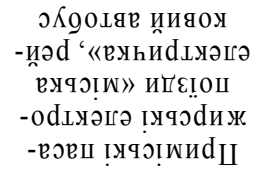 \\
\hline 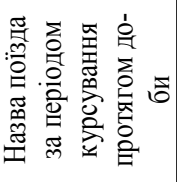 & 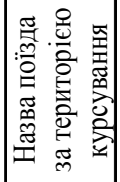 & 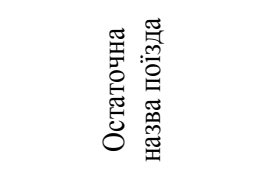 & 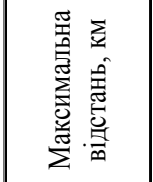 & 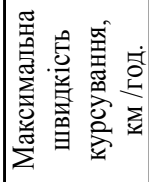 & 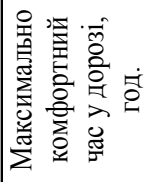 & 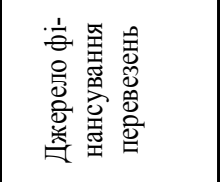 & 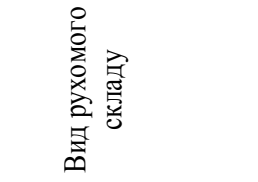 \\
\hline
\end{tabular}

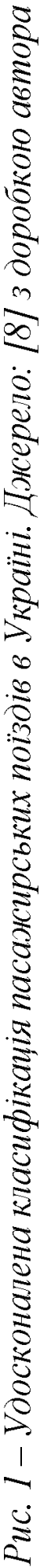


Належне фінансування підприємств міського рейкового транспорту дозволить створити умови для їх беззбиткової діяльності, залучення додаткових інвестицій та пріоритетного розвитку.

Висновки за даними дослідженнями та перспективи подальших досліджень у даному напрямку. На основі проведених автором досліджень можна зробити такі висновки:

1. Використання удосконаленого термінологічного поняття «міський рейковий транспорт» дозволить раціонально використовувати усі види рейкового транспорту у великому місті та оптимізувати витрати на їх розвиток і експлуатацію.

2. Використання

удосконаленої класифікації пасажирських поїздів в Україні дозволить розширити кордони експлуатації залізничного транспорту та скоротити витрати місцевих бюджетів при перевезенні населення 3 приміської зони у велике місто.

Наукова новизна. 1. Запропоновано удосконалене термінологічне поняття «міський рейковий транспорт», яке відрізняється від існуючого включенням усіх можливих видів рейкового міського транспорту, а саме: трамвая, швидкісного трамвая, метротрама, метрополітена, швидкісного трамвая на гумовому ходу, міських пасажирських електропоїздів, рейкового автобуса, вагонатрамвая, що дозволить раціонально використовувати їх у великому місті та оптимізувати витрати на розвиток та експлуатацію міського транспорту.

2. Набула подальшого розвитку існуюча класифікація пасажирських поїздів в Україні, яка додатково включає міський рейковий транспорт, для якого застосовуються залізничний рухомий склад, а саме електропоїзди та рейковий автобус, що дозволить скоротити витрати місцевих бюджетів при перевезенні населення з приміської зони у велике місто.

\section{СПИСОК ЛІТЕРАТУРИ}

1. Безлюбченко О. С., Завальний О. В. Урбаністика: Навч. Посібник [Текст] / О. С. Безлюбченко, О. В. Завальний. - Харків: ХДАМГ, 2003. $-254 \mathrm{c}$.

2. Процько Я. І. Вплив аварійних ситуацій на довкілля у роботі залізничного транспорту [Електронний ресурс]. - Режим доступу: http://archive.nbuv.gov.ua/portal/chem_biol/vpdaa/201 0_1/183.pdf. - Назва з екрану.
3. Сидоренко Ю. В. Дослідження тенденцій розвитку міського електротранспорту країн СНД. [Текст] / Ю. В. Сидоренко // Вісник економіки транспорту і промисловості. - 2010. - № 30. - С. 57 60.

4. Доля В. К. Пасажирські перевезення : підручник / В.К. Доля. - Харків : «Вид-во «Форт», 2011. -504 c.

5. Ефремов И. С. Теория городских пассажирских перевозок / И.С. Ефремов, В. М. Кобозев, В. А. Юдин. - М.: Высшая школа, 1980. $535 \mathrm{c}$.

6. Варелопуло Г. А. Организация движения и перевозок на городском пассажирском транспорте / Г. А. Варелопуло. - М.: Транспорт, 1981. - 200 с.

7. Анализ особенностей выбора пассажирского вида транспорта при городских пассажирских перевозках / В. И. Торкатюк, М. В. Юров, А. Ю. Палант, А. И. Кириченко, С. А. Ларина // Коммунальное хозяйство городов : науч.техн. сб. - Вып. 85. - Киев : Техніка, 2008. - С. 7278.

8. Палант А. Ю. The Stochastic Model of Reliability for City Public Transport Operation / Палант А.Ю., Адаменко Н.И. // Молодой ученый. Чита - 2013. - №8. - С. 67-69.

9. Адаменко М. I. Економіко-технічна надійність експлуатації міського електричного транспорту : монографія / М.I. Адаменко, О.Ю. Палант. - Харків : Золоті сторінки, 2014. - 144 с.

10. Корженевич I. П., Бараш Ю. С., Мельянцова Ю. П. Сучасний підхід до вибору транспортної системи великого міста. [Текст] / І. П. Корженевич, Ю. С. Бараш, Ю. П. Мельянцова // Вісн. Дніпропетр. нац. ун-ту залізн. трансп. ім. акад. В. Лазаряна. - Д.: Вид-во Дніпропетр. нац. унту залізн. трансп. ім. акад. В. Лазаряна, 2009. - Вип. 15. - C. $225-232$.

11. Пита А. Л. Международные пассажирские и железнодорожные сообщения в Европе // Железные дороги мира, 2001, № 7. - с. 11-15

12. Мельник Т. С. Концептуальні основи нової системи класифікації пасажирських поїздів українських залізниць. [Текст] / Т. С. Мельник // Вагонный парк. - 2012. - № 1(58). - с. 42-45

13. Мельник Т. С. Побудова системи сервісного обслуговування пасажирів відповідно до нової класифікації пасажирських поїздів українських залізниць. [Текст] / Т. С. Мельник // Вагонный парк. - 2012. - № 2 (59). - c. 44-49

14. Овчаренко Л. М. Высокоскоростное сообщение: частота важнее скорости [Текст] / Л. М. Овчаренко // Железные дороги мира. - 2010. - № 3. - с. 9-22

15. Лихушин Е. В. Опыт «Дойче Бан»: классификация пассажирских поездов [Текст] / Е. 
В. Лихушин // Локомотив-информ. - 2012 - № 01. c. $54-55$

16. Бакалінський О. В. Маркетинг пасажирських перевезень перспективними видами рухомого складу залізниць: теорія, методологія, практика. Дис. д.е.н.: 08.00.04 [Текст] / О.В. Бакалінський - Киів: ДЕТУТ - 2012 - 455 с.

17. Бараш Ю. С. Методика складання оптимального плану формування пасажирських поїздів / Ю. С. Бараш, В. В. Скалозуб // Економіка: проблеми теорії та практики: зб. наук. пр. - Д.: ДНУ,2005. - Вип. 205, т. 4. - С. 1186-1198.

18. Чаркіна Т. Ю. Нова класифікація пасажирських поїздів в Україні [Текст] / Т. Ю. Чаркіна // Вісник економіки транспорту i промисловості - 2012. - № 38. - с. 324-328.

Експерт редакційної колегії к.е.н., доцент УкрДУЗТ Боровик Ю.Т.

УДК 681.3:656.025.2

\title{
ІНФОРМАЦЙНІ ТЕХНОЛОГЇ̈ ПІДВИЩЕННЯ ЕФЕКТИВНОСТІ ПАСАЖИРСЬКИХ ПЕРЕВЕЗЕНЬ
}

\author{
Дикань В.Л., д.е.н., професор, \\ Слагін Ю.В., к.е.н., доцент (УкрДУЗТ)
}

Ефективність та якість в ринкових умовах в значній мірі визначається використанням сучасних інновачійних підходів, таких як логістика, процесний підхід та реінжиніринг. Застосування інновачійних підходів організації і технології пасажирських перевезень таких як реінжиніринг на базі розширення й удосконалення функиій АСУ ПП надає широкі можливості підвищувати ефективність обслуговування пасажсиів та функиіонування пасажирського комплексу в цілому.

Ключові слова: ефективність, реінжиніринг, автоматизовані системи

\section{ИНФОРМАЦИОННЫЕ ТЕХНОЛОГИИ ПОВЫШЕНИЯ ЭФФЕКТИВНОСТИ ПАССАЖИРСКИХ ПЕРЕВОЗОК}

\author{
Дикань В.Л., о.э.н., профессор, \\ Елагин Ю.В., к.э.н., доцент (УкрГУЖТ)
}

Эффективность и качество в рыночных условиях в значительной степени определяется использованием современных инновачионных подходов, таких как логистика, прочессный подход $и$ реинжиниринг. Применение инновачионных подходов организащии и технологии пассажирских перевозок как реинжиниринг на базе расширения и совершенствования функций АСУ ПП предоставляет широкие возможности повышать эффективность обслуживания пассажиров и функиионирования пассажирского комплекса в целом.

Ключевые слова: эффективность, реинжиниринг, автоматизированные системы

\section{INFORMATION TECHNOLOGY IMPROVING EFFICIENCY PASSENGER TRAFFIC}

Dikan V.L., doctor of economics, professor, Yelagin Y.V., Ph.D., associate professor (USURT)

Efficiency and quality in market conditions is largely determined by using modern innovative approaches such as logistics, process approach and reengineering. Productivity of passenger transport is a dynamic category which depends on external demand, the state's economy, population, and the level of 